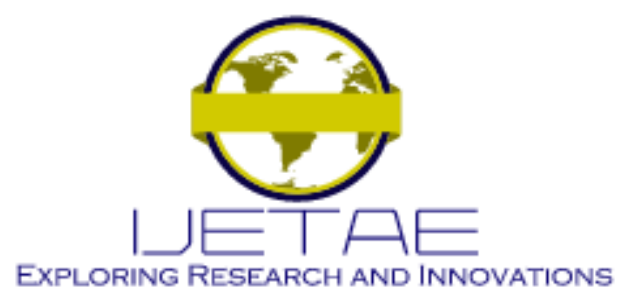

International Journal of Emerging Technology and Advanced Engineering

Website: www.ijetae.com (E-ISSN 2250-2459, Scopus Indexed, ISO 9001:2008 Certified Journal, Volume 11, Issue 07, July 2021)

Manuscript Received: 14 June 2021, Received in Revised form: 10 July 2021, Accepted: 13 July 2021 DOI: 10.46338/ijetae0721_08

\title{
Telemedicine Implementation Challenges in Underserved Areas of the Philippines
}

\author{
Luna A. Dela Cruz ${ }^{1}$, Lean Karlo S. Tolentino ${ }^{2}$ \\ ${ }^{1,2}$ Technological University of the Philippines, Manila, Philippines
}

\begin{abstract}
During these difficult times of global pandemic, mobility restrictions and lockdowns were put in place to prevent an outbreak. However, patients with medical needs must deal with regular face-to-face consultations with physicians for their prescriptions and medications. It is important to review the various telemedicine research in the Philippines and abroad and how to formulate a national framework for telemedicine so the program can be implemented in the entire country. As a developing nation and an archipelago, the Philippines needs to work on massive infrastructure project for national broadband and health care facilities. The increase of medical professionals per 1000 of population and prevent them from migrations will help implement such innovation in medical field. A national policy to support the program in terms of funding and its transparency, establishment of processes and standards, and safeguarding digital information should be put in place. The country will need to address these gaps in technology and processes and encourage the population to partake in national health plans and initiatives to increase awareness and engagement of all stakeholders.
\end{abstract}

Keywords - Challenges, Developing Countries, eHealth, Implementation, IoMT, Philippines, Rural, Telehealth, Telemedicine, Underserved

\section{INTRODUCTION}

The Corona Virus Disease of 2019 (COVID-19) prompted governments to impose quarantine protocols including lockdowns to prevent the transmission of the disease. Because of this, certain services must be performed online including medical consultations and monitoring called Telemedicine. It uses the rising technology of IoT or Internet of Things which is basically numerous devices' interconnection to the internet which has seen a significant application in medical practice on the onslaught of the global pandemic. The access and link of the medical devices to the internet can accommodate remote monitoring, diagnosis and prescription without the patient and health worker going to the health facility, thus preventing human to human contact. In a country such as the Philippines, there is a challenge on the implementation of telemedicine in the underserved areas.
As an archipelago, the interconnection of islands is vital in the delivery of health service in the rural areas. As a developing country, the government needs to create policies to understand and identify the gaps that would support modern medical and technological trends such as telemedicine. With the emergence of new knowledge and applications in the field of Information and Communication Technology (ICT), this can be used to bridge the gap in terms of distance to give equal services in all parts of the archipelago with the proper establishment of necessary infrastructure, addition of knowledge capital and leveraging resources. The present government form of having barangays could help in mobilizing the needed structure in the management of telemedicine related services to provide such service to the far-flung outskirts of the country.

\section{Methodology}

In this literature review, the authors analyzed research about IoMT, telehealth and telemedicine conducted in different countries to see the gap and challenges of its implementation in Philippine setting. Papers were analyzed especially those that involved research for countries with the same geographical and economic settings as the Philippines. For example are those papers about its geographical peers in Association of Southeast Asian nations (ASEAN) [1], research works that involve Indonesia [2] and Maldives [3] which have the same geographical setting as an archipelago, and those countries that belong to the Lower - Middle Income Countries (LMIC) in terms of economic activity and purchasing power [1]. Further analysis was done to published works about the implementation of IoMT, telehealth and telemedicine in the Philippines, including lessons on Lower Middle-Income economies [4], study on urban community and how to innovate telemedicine application [5], and a possible establishment of Biomedical Engineering [6] to bridge the gap and compare with international practice to determine things that can only be applied to the Philippines. 


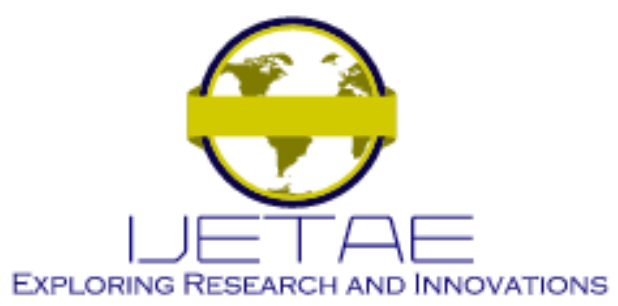

International Journal of Emerging Technology and Advanced Engineering

Website: www.ijetae.com (E-ISSN 2250-2459, Scopus Indexed, ISO 9001:2008 Certified Journal, Volume 11, Issue 07, July 2021)

The challenges based on the results are combination of technological, government policy and other societal issues. With this, additional research was done outside the published papers to support the information gathered and used in this literature review especially those pertaining to statistics on population [7], economy [8] and relevant government policies and legislations such as Philippine Health Insurance Corporation (PhilHealth) [9], Department of Information and Communications Technology (DICT) [10], National Electrification Administration (NEA) [11], Department of Health (DOH) [12], Department of Science and Technology (DOST) [13], and Department of Budget and Management (DBM) [14].

\section{Literature ReVIEW, Methodology Results, DISCUSSION, AND RECOMMENDATION}

Several studies have been conducted to support Telemedicine such as the impact of IoT in healthcare using network sensors worn in body or embedded in the environment [15], the use of latest technologies like cloud computing and fog computing in IoT [16], the use of biosensors in saliva test on hormonal imbalance for women living in the rural areas [17], the used of Field Programmable Gate Array (FPGA)-based IoT architecture in remote monitoring of patients' vital signs [18] and symptoms of cognitive impairment [19]. The application of the IoT to the medical field is called IoMT or Internet of Medical Things that can be used in remote medical supervision [21], real-time monitoring and medical information system [22]. This also includes a wide variety of medical related services such as Artificial Neural Network (ANN) - based image analysis of tongue for health evaluation [23] and circulatory system disease detection through fingernails [24], integrated circuit-based energy harvesting for wearable devices [25], Arduinobased pulse detector [26], blood glucose analysis through artificial raindrop algorithm [27], microcontroller-based image recognition of urine constituents in urinalysis examination such as Red Blood Cell (RBC), White Blood Cell (WBC), Bacteria, and Calcium Oxalates [28], and the development of wavefront technology to help eye checkup in the Philippines especially in rural areas [29]. Telehealth is a category under IoMT which deals technology-related services [30] while telemedicine narrows down into specific activities such as wireless diagnostics and monitoring, communication results [31] and reports and information dissemination [32].
Fig. 1 shows the application of IoT to different fields with emphasis on telehealth and telemedicine.

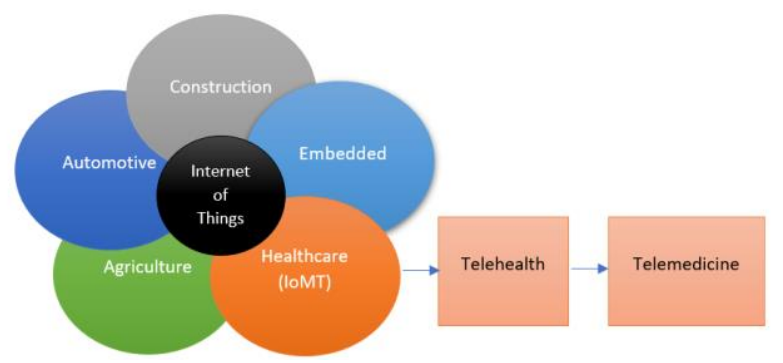

Fig. 1. Industrial Application of Internet of Things [33], showing IoMT and subcategories [32].

The Philippines as an archipelago with 7,641 islands [34] will be a perfect but challenging setting of telemedicine as there is a need for remote applications of medicine to ensure delivery of services to the underserved areas. In order to do this, several factors should be met to support the program and challenges should be identified and resolved. With a population of more than 110 million, the country is the $13^{\text {th }}$ most populous in the world and second in the regional peer of Association of Southeast Asian Nation (ASEAN) [7]. Categorized at lower-middle income group, the GNI (Gross National Income) per capita stands at US $\$ 3850$ [8]. It is subdivided into 81 provinces with 146 cities and 1488 municipalities, and is furthermore subdivided into 42,046 barangays which is the basic unit of its government [35].

In the study conducted by Macabasag et al. [4] about the lessons learned of Lower Middle-Income Countries that can be learned and applied by the Philippines in the implementation of telemedicine, several key points have been discussed. However, the discussion did not dwell on specificity of factors and challenges of the Philippines in the implementation of the said program.

\section{A. Density of Health Care Professionals}

Many countries have attempted to set up telemedicine processes and one country according to a study has relatively succeeded [36]. Maldives, which is a country in Indian Ocean conducted interviews to its localities on the present situation of the population and determined the gap of the implementation of telemedicine. To perform this in a Philippine setting, a similar endeavor will require manpower with combination of medical and non-medical trained resources. 


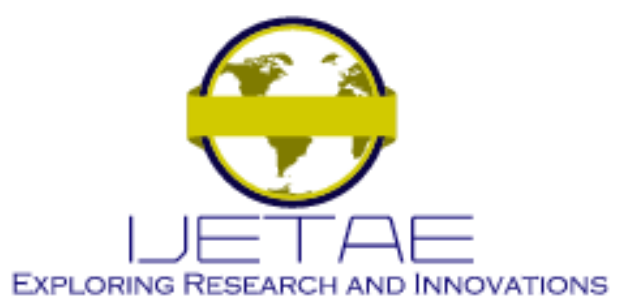

International Journal of Emerging Technology and Advanced Engineering

Website: www.ijetae.com (E-ISSN 2250-2459, Scopus Indexed, ISO 9001:2008 Certified Journal, Volume 11, Issue 07, July 2021)

The Philippines can tap the presently employed Barangay Health Workers [37] but needs to be reinforced with medically trained professionals. In Table I below, the Philippines is in lower half of its ASEAN peers in terms of Physicians per 1000 individuals at 0.6 compared to Maldives at 4.56 Physicians per 1000 individuals. Table II shows the number of nurses and midwives per 1000 individuals, where the Philippines fared well compared to ASEAN counterparts at 4.94 but still trailing behind Maldives at 6.42. It is good to note that Maldives has 1192 islands with the population of Maldives is 557, 426 individuals [38] compared to the Philippines with 7641 islands and population of 110 million.
After the interview for assessment, the number of medical professionals should be increased to cater the need of the population in the rural areas. In relation to telemedicine, there is also a need to increase professionals that are trained technologically to understand the complexity of the relationship of health and technology to underscore its benefits. This could pave way for new emerging medical professional field such as Biomedical Engineering [6] and establishment of such program is imperative and could be a game changer in increasing the number relevant health professionals in the country.

TABLE I

The NUMber of Physicians Per 1000 POPUlation for ASEAN COUNTRIES ANd MALdives [3].

\begin{tabular}{|c|c|c|c|c|}
\hline Country Name & $\mathbf{2 0 1 5}$ & $\mathbf{2 0 1 6}$ & $\mathbf{2 0 1 7}$ & $\mathbf{2 0 1 8}$ \\
\hline $\begin{array}{c}\text { Brunei } \\
\text { Darussalam }\end{array}$ & 1.7812 & & 1.609 & \\
\hline Indonesia & 0.2738 & & 0.3767 & 0.4269 \\
\hline Cambodia & & & & \\
\hline Lao PDR & & & 0.3726 & 0.677 \\
\hline Myanmar & & 0.6195 & 0.8638 & \\
\hline Malaysia & 1.5358 & & & 0.6004 \\
\hline Philippines & & & & 0.805 \\
\hline Singapore & & 2.2936 & 0.8075 & 0.7724 \\
\hline Thailand & 0.4651 & 0.445 & & \\
\hline Timor-Leste & 0.6946 & & 0.7504 & 4.5627 \\
\hline Vietnam & 0.7963 & 0.8281 & & \\
\hline Maldives & 2.8863 & 1.0379 & 3.7728 & \\
\hline
\end{tabular}

TABLE III

THE NUMBER OF NURSES AND MidWIVES PER 1000 POPULATION FOR ASEAN COUNTRIES AND MALDIVES [39].

\begin{tabular}{|c|c|c|c|c|}
\hline Country Name & $\mathbf{2 0 1 5}$ & $\mathbf{2 0 1 6}$ & $\mathbf{2 0 1 7}$ & $\mathbf{2 0 1 8}$ \\
\hline $\begin{array}{c}\text { Brunei } \\
\text { Darussalam }\end{array}$ & 6.6426 & 6.4721 & 6.0989 & 5.8974 \\
\hline Indonesia & 1.299 & & 2.0532 & 2.4149 \\
\hline Cambodia & 0.5889 & 0.7195 & 0.7007 & 0.6855 \\
\hline Lao PDR & 1.05 & 1.0304 & 1.2643 & 0.9522 \\
\hline Myanmar & 0.3824 & 1.0343 & 1.0054 & 0.9993 \\
\hline Malaysia & 3.3595 & 3.397 & 3.4676 & \\
\hline Philippines & 0.24 & & 5.2744 & 4.9351 \\
\hline Singapore & 6.0092 & 6.1678 & 6.2432 & \\
\hline Thailand & 2.3683 & 2.7724 & 2.9573 & 2.7593 \\
\hline Timor-Leste & 1.4821 & & 1.7413 & 1.668 \\
\hline Vietnam & 1.4228 & 1.4463 & & \\
\hline Maldives & 6.5729 & 3.9504 & 6.4927 & 6.4282 \\
\hline
\end{tabular}




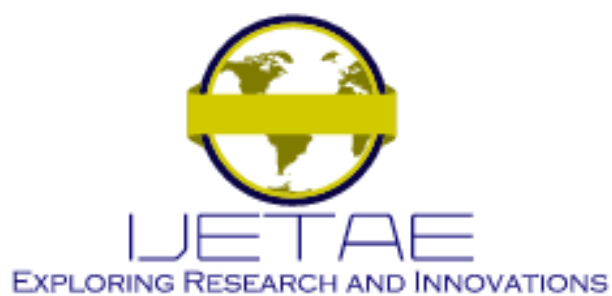

International Journal of Emerging Technology and Advanced Engineering

Website: www.ijetae.com (E-ISSN 2250-2459, Scopus Indexed, ISO 9001:2008 Certified Journal, Volume 11, Issue 07, July 2021)

In the study of Suzuki et. Al [1], the authors surveyed 11 Asian countries and 13 African countries that majority belong to LMIC group. The Asian countries included are the 6 largest economies of Southeast Asia: Indonesia, Thailand, Philippines, Malaysia, Singapore and Vietnam. The paper evaluated significant factors that will led to a conclusion that a certain country can adapt telemedicine including percent of health workers (physicians, nurses and midwives) using the internet, number of mobile contracts, and the health workers density per population. The Philippines was grouped in cluster $\mathrm{C}$ with a high likelihood of accommodating telemedicine practice but needs to improve on number of health personnel and their internet usage rates.

\section{B. Funding Telemedicine}

Based on the Budget Briefer of the Department of Health - Philippines, the amount of funding for the Republic Act 11223 also known as Universal Health Care (UHC) act of the Philippines is Php 209.26 B from different sources [40]. In section 36.5 of the said law, there is a move to promote the integration of telemedicine and improvement in efficiency in various health processes in the country. However, there is no specific allocation in the General Appropriation Act of 2021 dedicated to telemedicine and other related medical practice [41]. The UHC act was just signed last February 20, 2019 [42] and it is just in the early years of inception. Basic services and policies will be put in place first and other services such as telemedicine might fall behind in terms of priority.

\section{Whole of Community Approach}

The Philippines, although was able to pass a Universal Health Care law still need to catch up with other countries that has long been implementing their respective versions of UHC. The Philippines will need to improve in primary health care system in underserved areas. Together with the increase of health care professionals deployed in all its barangays, primary health care system will ensure that each barangay will have a record of medical profile of all the all its constituents, in return the country will have a profile for all citizens. The country already has a primary health care system since 1981 [43] but it needs to inculcate awareness to strengthen the program to benefit innovation in health care system such as telemedicine. The system should change from a curative approach into a preventive one. Relevant health related topics can also be included in primary education curriculum to teach students.
Information dissemination through advertisement in all media can also help increase the awareness of the community and increase the trust of the population in the health care system of the country.

\section{Technological Requirement}

The full implementation of telemedicine depends on the internet and broadband infrastructure of the country. The system will further require sensor technology for gadgets, Big Data analysis, Cybersecurity, and Intelligent Network [7]. Collection, management, and the security of data for population of 110 million will require certain technological advancement in a national scale.

\section{1) National Broadband:}

In a study about internet connection of the Philippines in 2016 [44], the average internet speed is $2.8 \mathrm{Mbps}$ compared to some developing countries in Asia such as Thailand and Sri Lanka both at 7.4 Mbps, and Malaysia at 4.3 Mbps. The internet speed of the country is dwarfed by developed countries such as Singapore at $12.9 \mathrm{Mbps}$ and South Korea at 23,6 Mbps. In November of 2020, the country ranked 110 out of 139 for mobile internet speed at $18.49 \mathrm{Mbps}$ and ranked 103 out of 176 at 28.69 Mbps [45]. Although there has been a call from the Department of Information and Communication Technology (DICT) for increased budget for the national broadband, the country has been lagging for a decade or quarter of a century in the establishment of national broadband compared to its Asian counterparts. South Korea started the Korean Information Infrastructure Project way back in 1995 and now enjoys one of the fastest internet connections in the world. Indonesia and Vietnam have also allocated funds and started their respective national broadbands [46]. The Philippines needs to fast track the establishment of the broadband project not just to improve the internet connection for public consumption and support the digitization of its economy, but also to allow industries including but not limited to health sector, to enjoy the benefit of a digital economy and modernize their way of conducting their businesses.

\section{2) Big Data Management:}

The large volume of data collected from a specific process is called Big Data [47] [20]. Collection of data from the population of 110 million will be considered as big data. However, the data gathered from the information of the population may be structured and unstructured. 


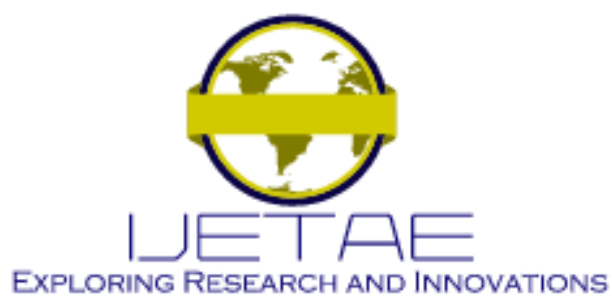

International Journal of Emerging Technology and Advanced Engineering

Website: www.ijetae.com (E-ISSN 2250-2459, Scopus Indexed, ISO 9001:2008 Certified Journal, Volume 11, Issue 07, July 2021)

It is also noteworthy that the data may be incomplete for some records [22] [48] so data handling and processing algorithm such as machine learning is needed to be utilized to better understand and use the data. Massive amount data will also need adequate power and memory [16]. The system set up should include power sources and availability of memory and redundancy for backup. The increase in number of sensors and gadgets for telemedicine will drive the power consumption of the country. According to the report of World Bank [49], only $92.5 \%$ of rural Philippines have access to electricity as of 2018. In the study of clinicians' perception of telemedicine in Indonesia [2], it was found out that internet connectivity and accessibility to power were the main impediments of the program. The National Electrification Administration targets 100\% power coverage for the entire Philippines in 2022 [11]. This will be a welcome development to the countryside as opportunities will open on their horizon igniting the rural economies and will give prospects to needed technologydriven methods replacing obsolete system of paper bureaucracy including in the field of health care such as telemedicine.

\section{3) Cyber Security:}

Another challenge of telemedicine is securing the data from cyber-attacks and hacking. The unencrypted data for IoT device is about $98 \%$ which makes $57 \%$ of all IoT device defenseless from hacking [50]. Maintaining confidentiality to keep the information private, maintaining integrity to ensure the completeness of the data and ensuring its availability to avoid disruption of operations are the goals of cybersecurity [51]. In March of 2016, over 54 million voter's information of the Philippines and 1.3 million passport numbers of Overseas Filipino Workers were hacked by using SQL injection in the server of voter's database [10]. The National Cyber Security Plan 2022 is aimed to address the shortcomings in the past and making sure will not happen again. The Philippines will need to safeguard the data of its population collected through telemedicine. Aside from the network and system functional well-being, cyber-attacks are also harmful to the information and the individuals in the database [52]. Information such as diagnostic report, disease and medication and other relevant material should be secured away from non-essential unauthorized individuals.
Moreover, relevant and necessary trainings should be given to health professionals and technical resources in order for them to be aware and compliant with standard on data privacy and protection of the customer's information.

\section{4) Artificial Intelligence:}

Artificial Intelligence (AI) is the use of collected big data from digital sensors and gadgets to analyze information, predict scenarios and recommend solutions to the benefit of customers and clientele through AI customer service [53] and authentication for user identity [54]. The challenge for telemedicine is to put emphasis on preventive medicine since the distance will no longer be a factor between patient and health professional. According to several studies, AI has been used in automatic screening of diabetic retinopathy [55], coordination and management of breast cancer [56], clinical deployment of prostate cancer diagnosis [57], detection and classification of chronic noncommunicable diseases [58], heart disease prediction [59], pneumonia detection [60], health screening [61], urinalysis examination [62], classification of skin diseases [63], and referral system [64] and voice controlled navigational aid [65] for visually impaired patients. Based on the studies, telemedicine can use AI for the purpose of diagnostics, communication of cure and medication, and monitoring of patients after surgery on the way to recovery or telerehabilitation after the pandemic [20], and before the pandemic [66]. A study also laid out the challenges of telerehabilitation to a developing country [67]. On the other hand, data acquisition from telerehabilitation system [68] could pave way for further application of AI in medical field. The collective web of technology will need massive data campaign to all stakeholders: health workers, technical resources, and the population in order to reap the benefits of $\mathrm{AI}$ and similar technologies.

\section{E. Government Legislation and Policies}

The role of the government does not end on the passing and implementation of the Universal Health Care Act. Necessary guidelines and policies should be put in place to guide local government and managers for the implementation of the program.

\section{1) Medical Regulatory and Ethical Standards:}

The nationwide implementation of telemedicine will require a national standard as a guide to every local government. 


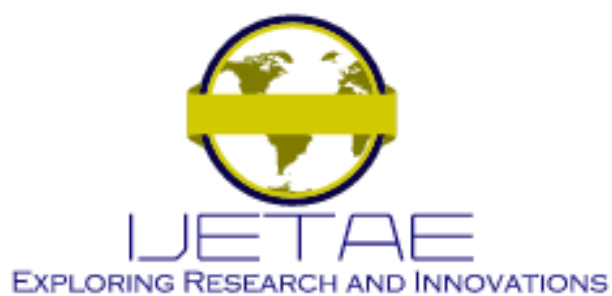

International Journal of Emerging Technology and Advanced Engineering

Website: www.ijetae.com (E-ISSN 2250-2459, Scopus Indexed, ISO 9001:2008 Certified Journal, Volume 11, Issue 07, July 2021)

The policy framework begins with the safeguarding of the data of the population. With this, the policy can set certain process on seeking consent of the individual before joining the telemedicine program and up to what extent the information can be used and the limitation of number of personnel or professional career level that are allowed access to the information [69]. The licensing requirements for the medical personnel are being implemented by the Professional Regulation Commission (PRC) [70]. According to telemedicine Department Center of Asia (TEMDEC), the Philippines telemedicine practice has started and now expanding to beyond urban centers [71]. In terms of process flow, the study of Kurata [5] laid out a proposed process for telemedicine in urban centers of the Philippines. A national standardized process may be enacted into official policy or the local government can tailor the process according to the specific needs and situations of their constituents. It will also help to put in place service level performance indicators in relation to the technicalities between the patient and medical personnel [72]. The policy should include but not limited to the suggested number of meetings and its frequency between medical personnel and patient and waiting time for the availability of reports and diagnosis. A policy should also be in place regarding the inclusion of the telemedicine related expenses for co-pay and deductibles and other related compensation for individuals that are victims of medical malpractice [69] and liability risk [72]. A reimbursement policy is also needed for supplementation on the steps and eligibility requirements for reimbursement if needed [73].

\section{2) Health Facilities and Services:}

There is no doubt that the passing of the Universal Health Care Act is a significant milestone in Philippine history. However, some flaws of the law have been surfacing out that could derail its full implementation and the progress of other services like telemedicine that depends on it.
According to Section 10 of the said Republic Act in Table III below, three percent of working individual's monthly income this year will be deducted as contribution. This means the contribution will be increased from the previous flat rate of $\mathrm{PhP} 2,400$ to maximum of PhP 21,600 annually [9].

With this changes, massive dissatisfaction erupted, and the President of the Philippines suspended the increase in contribution [74]. Despite this skyrocketing increase, the law does not include any performance indicator and national plan for the health services. Example of those key indicators would be:

- Increase the density of health-related personnel (physicians, nurses and midwives) per population to a certain level that will mirror or challenge the world leaders. According to World Bank data as of 2018, the world leaders Cuba has 8.422 physicians per 1000 individuals [3] and Belgium has 19.4614 nurses and midwives per 1000 individuals [39].

- Build Barangay Health Centers for each barangay, total of 42, 046 nationwide.

- Build Municipal and City hospitals for each municipality or city, total of 146 cities and 1,488 municipalities.

- Build world-class Provincial Hospital per province, total of 81 provinces and Regional Health Centers, total of 18 regions.

- Procure Ambulances and related medically equipped mobile transport per municipality or city.

- Inclusion of new emerging health related trends and technologies such as telemedicine in the allocation of budget. The cost of these programs will be compensated by reduced cost of travel, increase convenience, and improve the health situation of the population.

If these have been included as national plan and goal, this would really help the Philippines modernize its health system and would significantly increase the well-being of its population. 


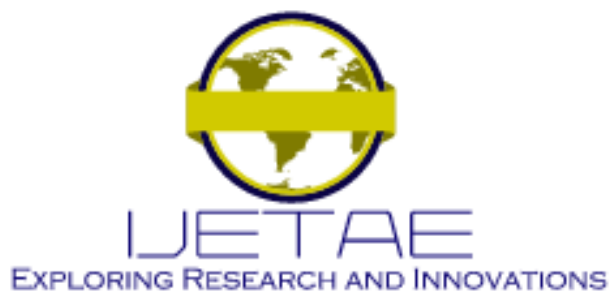

International Journal of Emerging Technology and Advanced Engineering

Website: www.ijetae.com (E-ISSN 2250-2459, Scopus Indexed, ISO 9001:2008 Certified Journal, Volume 11, Issue 07, July 2021)

TABLE IIIII

Individual Contribution Rates aCCORDing to Universal Health CaRe ACT [9].

\begin{tabular}{|c|c|c|c|}
\hline Year & $\begin{array}{c}\text { Premium Rate } \\
(\%)\end{array}$ & $\begin{array}{c}\text { Income Floor } \\
\text { (Php) }\end{array}$ & $\begin{array}{c}\begin{array}{c}\text { Income Ceiling } \\
\text { (Php) }\end{array} \\
\end{array}$ \\
\hline 2019 & 2.75 & \multirow{7}{*}{$10,000.00$} & $50,000.00$ \\
\hline 2020 & 3.00 & & $60,000.00$ \\
\hline 2021 & 3.50 & & $70,000.00$ \\
\hline 2022 & 4.00 & & $80,000.00$ \\
\hline 2023 & 4.50 & & $90,000.00$ \\
\hline 2024 & 5.00 & & $100,000.00$ \\
\hline 2025 & 5.00 & & $100,000.00$ \\
\hline
\end{tabular}

\section{3) Transparency of Funds:}

Another yet controversial but significant topic pertaining to health are the public funds and how they are being spent. With the massive national program such as the Universal Health Care, there is a need for transparency and accountability of public funds. The Executive branch of the Philippine government implemented Freedom of Information where documents can be requested [75]. Such practice should be continued and expanded to other branches of the government and be codified as an official law of the land. Providing proper accountability of public funds will increase the trust and confidence of the citizenry to the health care system.

\section{4) Scholarship Programs:}

Although, DOH are awarding scholarship grants to medical students [12], there should be nationwide campaign to promote scholarship programs for nurse, midwives, medical technologists, and pre-med courses for undergraduate students. The Department of Science and Technology (DOST) has been implementing a similar scholarship program under Republic Act 7687 since 1994 [13] that provides scholarship assistance to underprivileged brilliant and eligible students, but the recipient should pursue career in science and technology related courses. The DOH can copy this scholarship program and focus on medically aligned undergraduate courses to help the country increase the number of health-related personnel density per population.

\section{5) Skill-Based Compensation:}

In the study of Li et. al. about migration of nurses [76], the migration of health professionals like nurses from poor countries to wealthy countries are influenced by several factors such as overall compensation, job opportunities, quality of individual's and family's life, and sound retirement packages. Although the migration may come with stress, adjustments and often discrimination, the pros outweigh the cons. The benefits of the source countries are the remittances sent back home by the migrant workers.

The cost of education and other investment to this migrant health workers are being enjoyed by the receiving country. The burden and cost of education for these professionals are being carried by the poor countries. In this same study, it was approximated that $70 \%$ of nurses from the Philippines migrates to more developed and wealthier countries. There is an obvious dilemma of brain drain in the source country and the health care system is in jeopardy. Along with the recommendation in this paper to increase the number of health workers in the country by various program, there is also a need to look at the compensation, career and professional development, and over all work being of the said professionals.

Skill-based additional compensation in private corporation is a policy-backed bonus given to individuals with rare skill or one with high competency to perform a specific critical role or task [77]. The Philippine legislative bodies should enact laws that will increase the compensation packages for health workers given the exodus of these professionals. 


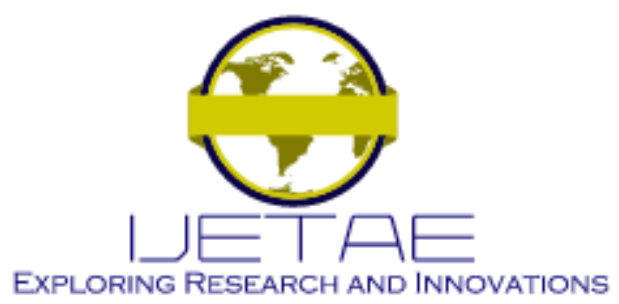

International Journal of Emerging Technology and Advanced Engineering

Website: www.ijetae.com (E-ISSN 2250-2459, Scopus Indexed, ISO 9001:2008 Certified Journal, Volume 11, Issue 07, July 2021)

In these challenging times of pandemic where health workers are in the greatest risk of being sick or to die, the outflow of medical workers put the country at risk because of shortage of skilled and highly trained individuals that will fight the pandemic. A similar salary increase was given to the police and military that can be replicated for medical workers [78]. With this, the authors propose that during a pandemic duly declared by the World Health Organization (WHO), the salary of medical doctors should be increased to salary grade 27 and salary grade 24 for other medical practitioners fighting the pandemic based on the National Budget Circular [14]. Of course, proper guidelines, criteria and competency assessment should be put in place to identify individuals with critical roles. There is also a need for periodical evaluation of meritocracy by relevant government agencies.

With this skilled-based pay program, health care professionals will be enticed to stay. This will increase the number of health professionals that would be available to serve the rural communities of the Philippines and can explore new technology-driven method to improve the health service of the country such as telemedicine.

\section{CONCLUSION}

The Philippines as a developing country and grouped under the Lower Middle-Income Countries can implement telemedicine for the entire country. Despite of its geographical landscape as an archipelago, there has been studies in other archipelagic countries about the successes of the said program which the Philippines can apply, and challenges of the program which it can learn from. The passing of the Universal Health Care is a good start and proof that the country is gearing towards the right path. Alongside with the law, additional policies should be put in place to increase the number of health professionals in the country and prevent them from leaving, include emerging trends such as telemedicine in the allocation of budget and guarantee its transparency, medical regulatory and standards for the said program, and protocol involving digital data collection, management and storage of information of the patients. There is also a need to fast track the national broadband as the internet backbone of the country to accommodate wireless and mobile technologies and innovations for all industries including that in the medical field such as telemedicine.
The infrastructure projects should also include creation of health centers in the far outskirts of the country including remote areas and habitable islands. Inculcate the importance of health in the population by massive media campaign and encourage community participation in activities that promote national health and well-being.

\section{REFERENCES}

[1] Suzuki, T., Hotta, J., Kuwabara, T., Yamashima, H., Ishikawa, T., Tani, Y., Ogasawara, K. (2020). Possibility of introducing telemedicine services in Asian and African countries. Health Policy and Technology. https://doi.org/10.1016/j.hlpt.2020.01.006

[2] Indria, D., Alajlani, M., Frase, H. (2020). Clinicians perceptions of a telemedicine system: a mixed method study of Makassar City, Indonesia. BMC Medical Informatics and Decision Making. https://doi.org/10.1186/s12911-020-01234-7

[3] The World Bank. Physicians (per 1,000 people). Last accessed $29^{\text {th }}$ December 2020: https://data.worldbank.org/indicator/SH.MED.PHYS.ZS?end=2018 \&start=2018\&view=map\%20(Physician\%20per\%20population)

[4] Macabsag, R.L., Magtubo, K.M., Fernandez-Marcelo, P. G. (2016). Implementation of Telemedicine Service in Lower-Middle Income Countries: Lessons for the Philippines. Journal of the International Society for Telemedicine and Health, 1-8.

[5] Kurata, Y. (2020). Pandemic Response Based Healthcare Services System Architecture Among Urbanized Communities in The Philippines. Proceedings of the $5^{\text {th }}$ NA International Conference on Industrial Engineering and Operations Management Detroit, Michigan, USA, August $10 \quad$ - 14, 2020 https://www.researchgate.net/publication/344207261

[6] Tan, M.J., Fermin, J. (2020). The Need for the Establishment of Biomedical Engineering (BME) as an Academic and Professional Discipline in the Philippines - A Quantitative Argument. TechRxiv. Preprint. https://doi.org/10.36227/techrxiv.13108019.v2

[7] The World Bank. Population, total. Last accessed $13^{\text {th }}$ December 2020: https://data.worldbank.org/indicator/SP.POP.TOTL

[8] The World Bank. GNI per capita, Atlas method (current US\$). Last accessed $13^{\text {th }} \quad$ December 2020 https://data.worldbank.org/indicator/ny.gnp.pcap.cd?year_high_desc $=$ true

[9] PhilHealth. UHC-IRR Signed. Last accessed $29^{\text {th }}$ December 2020: https://www.philhealth.gov.ph/about_us/UHC-IRR_Signed.pdf

[10] Department of Information and Communications Technology (2019, July 01). National Cybersecurity Plan 2022. Last accessed $4^{\text {th }}$ January 2021: https://dict.gov.ph/wpcontent/uploads/2019/07/NCSP2022-rev01Ju12019.pdf

[11] National Electrification Administration (2017, July 21). NEA Eyes 100 Percent Sitio Electrification by 2022. Last accessed $4^{\text {th }}$ January 2021: http://www.nea.gov.ph/ao39/147-nea-eyes-100-percent-sitioelectrification-by-

2022\#: :text=The $\% 20$ National $\% 20$ Electrification $\% 20$ Administratio n\%20(NEA,across \%20the \%20country\%20by\%202022.\&text=Maso ngsong\%20said\%2023\%2C464\%20sitios\%20in,more\%20or\%20less $\% 20 \mathrm{P} 1 \% 20$ million. 


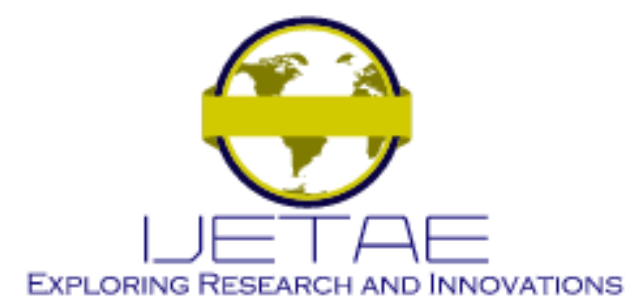

International Journal of Emerging Technology and Advanced Engineering Website: www.ijetae.com (E-ISSN 2250-2459, Scopus Indexed, ISO 9001:2008 Certified Journal, Volume 11, Issue 07, July 2021)

[12] Department of Health (2019, March 05). Acceptance of Scholars and Partner Schools for the Department of Health Pre-Service Scholarship Program for School Year 2019-2020. Last accessed $9^{\text {th }}$ January 2021: http://caro.doh.gov.ph/wpcontent/uploads/2019/04/dm2019-0119.pdf

[13] Department of Science and Technology. Undergraduate Scholarship. Last accessed $9^{\text {th }} \quad$ January 2021: http://www.sei.dost.gov.ph/index.php/programs-andprojects/scholarships/undergraduate-scholarships\#s-amp-tundergraduate-scholarships

[14] Department of Budget Management (2020, January 24). National Budget Circular 579. Last accessed $9^{\text {th }}$ January 2021: https://www.dbm.gov.ph/wpcontent/uploads/Issuances/2020/National-BudgetCircular/NATIONAL-BUDGET-CIRCULAR-NO-579-datedJanuary-24-2020.pdf

[15] Sinha, A. (2020). Investigation of machine Learning Application in Healthcare. International Journal of IOT. https://www.researchgate.net/publication/344501236

[16] Thilakarathne, N., Kagita, M., Gadekallu, T., (2020). The Role of the Internet of Things in Health Care: A Systematic and Comprehensive Study. International Journal of Engineering and Management Research. https://doi.org/10.31033/ijemr.10.4.22

[17] Jorda, R. J., Bartolome, K. E., Buban, C., De Los Reyes, M. A., Maingat, A., Oledan, M. J., Tolentino, L. K. (2019). Ovulation hormonal imbalance recognition system using saliva's conductivity analysis based on potentiometric method. Indonesian Journal of Electrical Engineering and Computer Science, 16(1), 176-183.

[18] Cruz, R. T. M., Tolentino, L. K. S., Juan, R. S., Kim, H. S. (2019). IoT-based monitoring model for pre-cognitive impairment using $\mathrm{pH}$ level as analyte. International Journal of Engineering Research and Technology, 12(5), 711-718.

[19] Tolentino, L. K. S., Cruz, R. T. M., Raguindin, E. Q. (2019). 047| Cognitive impairment monitoring system via Long Range (LoRa) low-power wireless communication using $\mathrm{pH}$ level. In Basic \& Clinical Pharmacology \& Toxicology, vol. 125, no. S9, pp. 32-33, 2019

[20] Ullah, W., Yahya, A., Samikannu, R., Tlale, T. (2020). Robust and Secured Telehealth System for COVID-19 Patients. https://www.researchgate.net/publication/343769380_Robust_and_S ecured_Telehealth_System_for_COVID-19_Patients

[21] Cecil, J., Gupta, A., Pirela-Cruz,M. (2018). An IoMT based cyber training framework for orthopedic surgery using Next generation Internet technologies. Informatics in Medicine Unlocked, https://doi.org/10.1016/j.imu.2018.05.002

[22] Mohammed, M., Desyansah, S., Al-Zubaidi, S., Yusuf, E. (2020). An internet of things-based smart homes and healthcare monitoring and management system: Review. Journal of Physics. doi:10.1088/1742-6596/1450/1/012079

[23] Velasco, J., Rojas, J., Ramos, J. P., Muaña, H. M., Salazar, K. L. (2019). Health Evaluation Device Using Tongue Analysis Based on Sequential Image Analysis. International Journal of Advanced Trends in Computers Science and Engineering, 8(3), 451-457.
[24] Tolentino, L. K., Aragon, R. M., Tibayan, W. R., Alvisor, A. Palisoc, P. G., Terte, G. (2018). Detection of Circulatory Diseases Through Fingernails Using Artificial Neural Network. Journal of Telecommunication, Electronic and Computer Engineering (JTEC), 10(1-4), 181-188.

[25] Wang, C.-C., Tolentino, L.K.S., Chen, P.-C., Hizon, J.R.E., Yen, C.K., Pan, C.-T., Hsueh, Y.-H., (2021). A 40-nm CMOS Piezoelectric Energy Harvesting IC for Wearable Biomedical Applications. Electronics, 10(6), p.649.

[26] Cabrales, D.D., Cuartero, J.R.M., Enriquez, L.A.C., Erne, J.G.Z., Galvadores, B.D.E.N., Millan, M.L.S., Monterona, B.K.C., Panergalin, J.V.P., Teodoro, M.N.G., Tolentino, L.K.S., (2019). Utilization of Pulse Rate Variability between Post-sleep and Wake Cycles to increase Alarm Clock Efficiency using Arduino-based Non-invasive Pulse Detector. arXiv preprint arXiv:1910.13082.

[27] Cuello, A., Dizon, K., Fortu, M. L., Paguia, J. G., Tañola, A. V., Velasco, J., Aquino, A., Valenzuela, I. (2017). Blood Glucose Analysis Utilizing Artificial Raindrop Algorithm and Capacitance Method. In 2017 International Conference on Computer and Applications (ICCA) (pp. 135-139). IEEE.

[28] Fernandez, E. O., Nilo, M., Aquino, J. O., Bravo, J. M. P., Francisco, J.-A. S., Gaddi, C. V. B., Simbran, C. A. (2018). MicrocontrollerBased Automated Microscope for Image Recognition of Four Urine Constituents. In TENCON 2018-2018 IEEE Region 10 Conference (pp. 1689-1694). IEEE.

[29] Atas, M.C.D., Landicho, L.M.T., Lobo, A.D., Orubia, C.J.L., Silverio, A.C.O., Aquino, A.U., Amado, T.M., Puno, J.C.V., Quijano, J.F.C., Arago, N.M., (2019). Development of Wavefront Sensor using Shack-Hartmann Principle. In 2019 IEEE 11th International Conference on Humanoid, Nanotechnology, Information Technology, Communication and Control, Environment, and Management (HNICEM) (pp. 1-5). IEEE.

[30] Bulman, J., Moussa, M., Lewis, T., Berkowitz, S., Sarwar, A., Faintuch, S., Ahmed, M. (2020). Transitioning the IR Clinic to Telehealth: A Single-Center Experience during the COVID-19 Pandemic. Division of Vascular and Interventional Radiology, Department of Radiology, Beth Israel Deaconess Medical Center/Harvard Medical School. https://doi.org/10.1016/j.jvir.2020.05.008

[31] Bhaskar S, Bradley S, Sakhamuri S, Moguilner S, Chattu VK, Pandya S, Schroeder S, Ray D, Banach M. Designing futuristic telemedicine using artificial intelligence and robotics in the COVID19 era. Frontiers in Public Health (2020). doi: 10.3389/fpubh.2020.556789

[32] Garajawala, S., Pelkowski, J. (2020). Telehealth Benefits and Barriers. The Journal for Nurse Practitioners https://doi.org/10.1016/j.nurpra.2020.09.013

[33] Mehta, R., Shani, J., Khanna, K. (2018). Internet of Things: Vision, Applications and Challenges. Procedia Computer Science. https://doi.org/10.1016/j.procs.2018.05.042

[34] Gov.ph. About the Philippines. Last accessed $13^{\text {th }}$ December 2020: https://www.gov.ph/about-the-philippines 


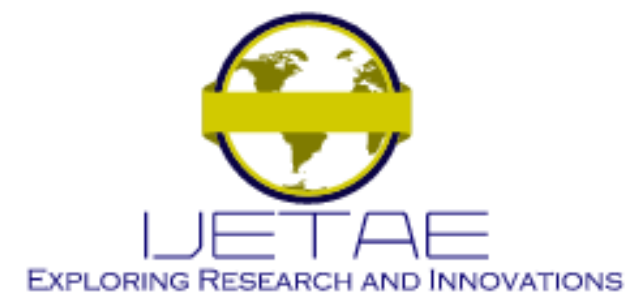

International Journal of Emerging Technology and Advanced Engineering Website: www.ijetae.com (E-ISSN 2250-2459, Scopus Indexed, ISO 9001:2008 Certified Journal, Volume 11, Issue 07, July 2021)

[35] Department of Interior and Local Government (2020, December 04). Regional and Provincial Summary - Number of Provinces, Cities, Municipalities and Barangays as of 30 September 2020. Last accessed $13^{\text {th }}$ December 2020: https://dilg.gov.ph/facts-andfigures/Regional-and-Provincial-Summary-Number-of-ProvincesCities-Municipalities-and-Barangays-as-of-30-June-2020/32

[36] Kodukula, S., Nazvia, M. (2011). Evaluation of Critical Success Factors for Telemedicine Implementation. International Journal of Computer $\quad$ Applications $\quad$ (0975 $\quad-\quad 8887)$ https://www.who.int/goe/policies/countries/mdv_support_tele.pdf

[37] Department of Health. Barangay Health Worker. Last accessed $29^{\text {th }}$ December 2020: https://doh.gov.ph/faqs/Barangay-Health-Workers

[38] National Bureau of Statistics. Maldives in Figures - October 2020. Last accessed $29^{\text {th }} \quad$ December 2020 : http://statisticsmaldives.gov.mv/maldives-in-figures-october-2020/

[39] The World Bank. Nurses and midwives (per 1,000 people). Last accessed $29^{\text {th }} \quad$ December 2020: https://data.worldbank.org/indicator/SH.MED.NUMW.P3?end=2018 \&start=2018\&view=map

[40] Department of Health. Budget Briefer. Last accessed $29^{\text {th }}$ December 2020: https://doh.gov.ph/sites/default/files/publications/2021Budget-Briefer.pdf

[41] Department of Budget and Management. General Appropriations Act (GAA). Last accessed $29^{\text {th }}$ December 2020: https://www.dbm.gov.ph/167-publications/general-appropriationsact-gaa

[42] World Health Organization (2019, March 14). UHC Act in the Philippines: a new dawn for health care. Last accessed $29^{\text {th }}$ December 2020: https://www.who.int/philippines/news/featurestories/detail/uhc-act-in-the-philippines-a-new-dawn-for-health-care

[43] Phillips, D. (1986). Primary health care in the Philippines: Banking on the barangays? Social Science \& Medicine. https://doi.org/10.1016/0277-9536(86)90269-8

[44] Salac, R., Kim Y. (2016). A Study on The Internet Connectivity in The Philippines. Asia-Pacific Journal of Business Review. https://doi.org/10.20522/APJBR.2016.1.1.67

[45] Speed Test Global Index. Global Speed November 2020. Last accessed $29^{\text {th }}$ December 2020: https://www.speedtest.net/globalindex\#mobile

[46] Department of Information and Communications Technology (2020, October 09) . DICT continues call for an increased 2021 national broadband budget. Last accessed $13^{\text {th }}$ December 2020: https://dict.gov.ph/dict-continues-call-for-an-increased-2021national-broadband-budget/

[47] de Hert, P., Papakonstantinou, V. (2020). Framing Big Data in the Council of Europe and the EU data protection law systems: Adding 'should' to 'must' via soft law to address more than only individual harms. Computer Law \& Security Review. https://doi.org/10.1016/j.clsr.2020.105496

[48] Aman, A., Hassan, W., Sameen, S., Attarbashi, Z., Alizadeh, M., Latiff, L. (2020). IoMT amid COVID-19 pandemic: Application, architecture, technology, and security. Journal of Network and Computer Applications. https://doi.org/10.1016/j.jnca.2020.102886
[49] The World Bank. Access to electricity, rural (\% of rural population) - Philippines. Last accessed $4^{\text {th }}$ January 2021: https://data.worldbank.org/indicator/EG.ELC.ACCS.RU.ZS?location $\mathrm{s}=\mathrm{PH}$

[50] Palandrani, P. (2020, April 15). How Cybersecurity Will Accelerate IoT's Growth. Last accessed $4^{\text {th }}$ January 2021: https://www.globalxetfs.com/how-cybersecurity-will-accelerate-iotsgrowth/

[51] Eggers, S. (2020). A novel approach for analyzing the nuclear supply chain cyber-attack surface. Nuclear Engineering and Technology. https://doi.org/10.1016/j.net.2020.08.021

[52] Bhat, M., Thippeswamy, V., Bhushan, H., Shrivastava, K., Sahoo, A. (2020). Secure Online Medicine Delivery System. Review of Computer Engineering Studies. https://doi.org/10.18280/rces.070305

[53] Xu, Y., Shieh, C., Esch, P., Ling, I. (2020). AI customer service: Task complexity, problem-solving ability, and usage intention. Australasian Marketing Journal. https://doi.org/10.1016/j.ausmj.2020.03.005

[54] Velasco, J., Fernandez, E., Adiao, G.J., Alarilla, E.B., Cano, P.C.L., De Lara, M., Grande, J.C., Nuevo, J., Valenzuela, I., Tolentino, L.K., (2019). User Authentication for Computer Security Based on Sound-to-Feature Algorithm and Artificial Neural Network Using Bone Conduction. Lecture Notes on Research and Innovation in Computer Engineering and Computer Sciences.

[55] Katada, Y., Ozawa, N., Masayoshi, K., Ofuji, Y., Tsubota, K., Kurihara, T. (2020). Automatic screening for diabetic retinopathy in interracial fundus images using artificial intelligence. Intelligencebased Medicine. https://doi.org/10.1016/j.ibmed.2020.100024

[56] Moser, E.C., Narayan, G. (2020). Improving breast cancer care coordination and symptom management by using AI driven predictive toolkits. The Breast. https://doi.org/10.1016/j.breast.2019.12.006

[57] Janowczyk, A., Leo, P., Rubin, M. (2020). Clinical deployment of AI for prostate cancer diagnosis. The Lancet Digital Health. https://doi.org/10.1016/S2589-7500(20)30163-1

[58] Vorobiev, A., Krasnova, L., Holownia-Voloskova, M., Oparin, I. (2019). Evaluation of the Safety and Efficacy of AI for Detection of Chronic Non-communicable Disease in Remote Areas. Value in Health. https://doi.org/10.1016/j.jval.2019.09.2189

[59] Tolentino, L.K.S., Isoy, J.E.L., Bulawan, K.A.A., Co, M.C.T., Monreal, C.F.C., Vitto, I.J.W., Padilla, M.V.C., Quijano, J.F.C., Jorda, R.J.L., Velasco, J.S., (2020). CAREdio: Health Screening and Heart Disease Prediction System for Rural Communities in the Philippines. International Journal of Advanced Computer Science and Applications, 11(8)

[60] Velasco, J., Ang, J. R., Caibigan, J., Naval, F. M., Arago, N., Fortaleza, B. (2020). Identification of Normal and Diseased Lungs using X-ray Images through Transfer Learning. International Journal of Advanced Trends in Computer Science and Engineering, 9(4).

[61] Tolentino, L.K., Co, M.C., Isoy, J.E., Velasco, J., Jorda Jr, R., Coronel, L., Fuentes, N. (2020). Development of Smart Health Screening System for Rural Communities in the Philippines. International Journal of Computing and Digital Systems, in press. 


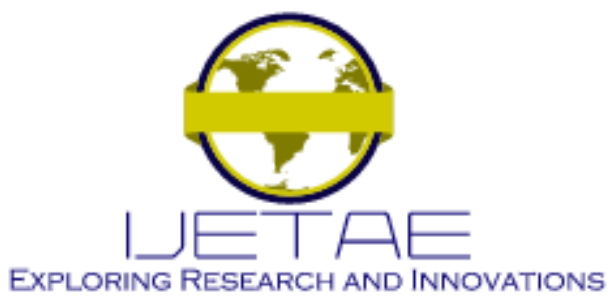

International Journal of Emerging Technology and Advanced Engineering Website: www.ijetae.com (E-ISSN 2250-2459, Scopus Indexed, ISO 9001:2008 Certified Journal, Volume 11, Issue 07, July 2021)

[62] Fernandez, E. O., Nilo, M., Aquino, J. O., Bravo, J. M. P., JulieAnne, S., Gaddi, C. V. B., Simbran, C. A. (2018). MicrocontrollerBased Automated Microscope for Image Recognition of Four Urine Constituents. In TENCON 2018-2018 IEEE Region 10 Conference (pp. 1689-1694). IEEE.

[63] Velasco, J., Pascion, C., Alberio, J.W., Apuang, J., Cruz, J.S., Gomez, M.A., Molina Jr, B., Tuala, L., Thio-ac, A. and Jorda Jr, R., (2019). A smartphone-based skin disease classification using mobilenet cnn. International Journal of Advanced Trends in Computer Science and Engineering, 8(5), 2632-2637.

[64] Alam, M., Hallak, J. (2021). AI-automated referral for patients with visual impairment. The Lancet Digital Health. https://doi.org/10.1016/S2589-7500(20)30286-7

[65] Madrigal, G. A. M., Boncolmo, M. L. M., Santos, M. J. C. D., Ortiz, S. M. G., Santos, F. O., Venezuela, D. L., Velasco, J. (2018). Voice Controlled Navigational Aid With RFID-based Indoor Positioning System for the Visually Impaired. In 2018 IEEE 10th International Conference on Humanoid, Nanotechnology, Information Technology, Communication and Control, Environment and Management (HNICEM) (pp. 1-5). IEEE.

[66] Leochico, C.F. (2020). Adoption of telerehabilitation in a developing country before and during the COVID-19 pandemic. Annals of Physical and Rehabilitation Medicine. https://doi.org/10.1016/j.rehab.2020.06.001

[67] Leochico, C.F., Espiritu, A.I., Ignacio, S., Mojica, J.A. (2020). Challenges to the Emergence of Telerehabilitation in a Developing Country: A Systematic Review. Frontiers in Neurology. https://doi.org/10.3389/fneur.2020.01007

[68] Galido, E., Esplanada, M.C., Estacion, C.J., Migriño, J.P., Rapisora, J.K., Salita, J., Amado, T., Jorda, R., Tolentino, L.K., (2019). EMG speed-controlled rehabilitation treadmill with physiological data acquisition system using BITalino kit. In 2018 IEEE 10th International Conference on Humanoid, Nanotechnology, Information Technology, Communication and Control, Environment and Management (HNICEM) (pp. 1-5). IEEE.
[69] Fields, B. (2020). Regulatory, Legal, and Ethical Considerations of Telemedicine. Sleep Medicine Clinics. https://doi.org/10.1016/j.jsmc.2020.06.004

[70] Professional Regulation Commission. Examination Services $\begin{array}{llll}\text { Physicians. } & \text { Last accessed } & 9^{\text {th }} \text { January } & \text { 2021: }\end{array}$ https://www.prc.gov.ph/requirements/physician

[71] Shimizu, S., Kudo, K., Tomimatsu, S., Moriyama, Tomohiko., Moriyama, Taiki., Sadakari, Y., Nakashima, N., Akaraviputh, T. (2018). International telemedicine activities in Thailand. Siriraj Medical Journal. doi: 10.14456/smj.2018.75

[72] Bruhn, H. (2020). Telemedicine: dos and don'ts to mitigate liability risk. Journal of American Association for Pediatric Ophthalmology and Strabismus. https://doi.org/10.1016/j.jaapos.2020.07.002

[73] Brotman JJ, Kotloff RM, Providing Outpatient Telehealth in the United States: Before and During COVID-19, CHEST (2020). https://doi.org/10.1016/j.chest.2020.11.020

[74] Parrocha, A. (2021, January 05). Duterte orders PhilHealth to defer contribution hikes. Philippine News Agency. Last accessed $9^{\text {th }}$ January 2021: https://www.pna.gov.ph/articles/1126332

[75] Freedom of Information. Last accessed $9^{\text {th }}$ January 2021: https://www.foi.gov.ph/requests?status=SUCCESSFUL\&category= \&search=DOH+budget

[76] Li, H., Nie, W., Li, J. (2014). The benefits and caveats of international nurse migration. International Journal of Nursing Sciences. https://doi.org/10.1016/j.ijnss.2014.07.006

[77] Ledford, G., Heneman, H. (2011, June). Skill-Based Pay. Society for Human Resource Management. Last accessed $9^{\text {th }}$ January 2021 : https://www.shrm.org/hr-today/trends-and-forecasting/specialreports-and-expert-views/Documents/SIOP\%20-\%20SkillBased\%20Pay,\%20FINAL.pdf

[78] Department of Budget Management (2017, December 21). Senate approves Joint Resolution on salary hike for police and military. Last $\begin{array}{llll}\text { accessed } & 9^{\text {th }} & \text { January } & 2021 \text { : }\end{array}$ https://www.dbm.gov.ph/index.php/secretary-s-corner/pressreleases/list-of-press-releases/398-senate-approves-joint-resolutionon-salary-hike-for-police-and-military 